\title{
Russell body gastritis in an Hp-negative patient
}

\author{
Artur Gião Antunes, ${ }^{1}$ Jesus Cadillá, ${ }^{2}$ Francisco Velasco ${ }^{1}$
}

${ }^{1}$ Gastroenterology Department, Centro Hospitalar do Algarve, Faro, Portugal

2Pathology Department, Centro Hospitalar do Algarve, Faro, Portugal

\section{Correspondence to} Dr Artur Gião Antunes, sergiogiao@hotmail.com

Accepted 26 July 2016

\section{DESCRIPTION}

A 79-year-old woman with a longstanding gastrooesophageal reflux disease was admitted to the emergency room for haematemesis without other symptoms. The patient presented hemodynamic stability and had a haemoglobin of $12.6 \mathrm{~g} / \mathrm{L}$. In the upper endoscopy the cause of bleeding was an $8 \mathrm{~mm}$ mucosal break in the lower oesophagus classified as grade B in the Los Angeles classification for oesophagitis. Also, we identified in the incisura angularis, a whitish and nodular area of mucosa, with indefinite margins that were biopsied (figure 1). Given the clinical and laboratorial presentation, the patient was discharged with a proton pump inhibitor and was re-evaluated as an ambulatory outpatient, with a good clinical evolution.

The histological examination (figure 2) revealed an infiltrate of plasma cells containing numerous eosinophilic inclusions at lamina propria and intestinal metaplasia (100\% of the glands). Subsequent testing for Helicobacter pylori $(\mathrm{Hp})$ infection was negative (stool antigen).

We established the diagnosis of Russell body gastritis in an Hp-negative patient.

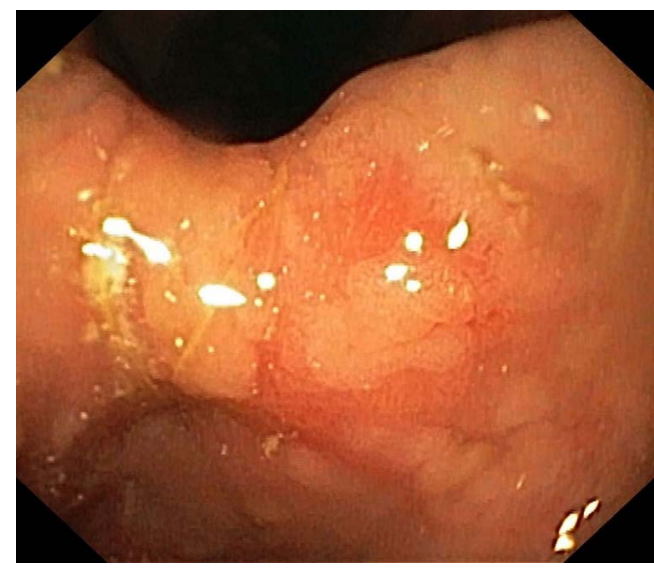

Figure 1 Upper endoscopy showing a whitish and nodular area of mucosa in the incisura angularis.
Given the uncertain prognosis of this entity, the patient continues to have clinical, laboratorial and endoscopic follow-up at our centre.

\section{Learning points}

- Russell body gastritis is an extremely rare entity with $<20$ cases reported in the literature and is characterised by infiltration of the lamina propria by plasma cells containing multiple eosinophilic inclusions in their cytoplasm, known as Mott cells (vacuoles of immunoglobulin). Its pathogenesis is unknown, although more often it is associated with Helicobacter pylori infection, which was not so in our case. ${ }^{1-3}$

- Although there are no specific endoscopic features for Russell body gastritis, there are reports describing it as an exophytic pseudotumoral lesion, infiltrative or simply manifesting as an area of nodular or scarring mucosa. $^{1-3}$

- It is generally considered a benign entity, but given its epidemiology and the fact that Mott cells are associated with certain haematological malignancies such as multiple myeloma, plasmacytoma and mucosaassociated lymphoid tissue (MALT) lymphoma there is still some doubts concerning its true clinical significance, particularly regarding the risk for gastric cancer development and so, follow-up is mandatory. ${ }^{1-3}$

Contributors AGA is the primary author of the article. Both JC and FV have participated in the conception, design and data acquisition of the data that has resulted in the manuscript in question.

Competing interests None declared.

Patient consent Obtained.
To cite: Antunes $A G$, Cadillá J, Velasco F. BMJ Case Rep Published online: [please include Day Month Year] doi:10.1136/bcr-2016216717
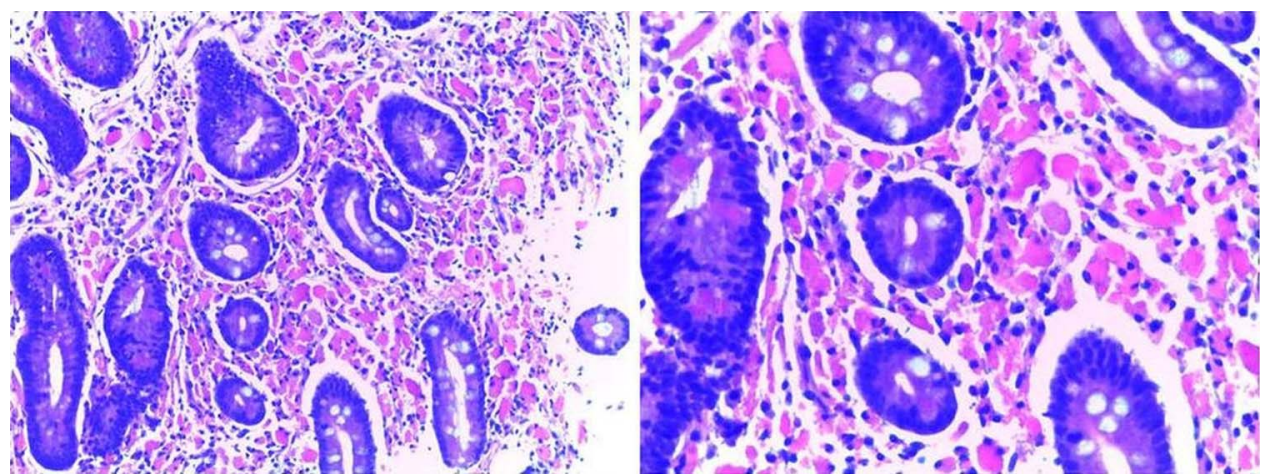

Figure 2 Massive infiltration of plasma cells containing numerous eosinophilic inclusions at lamina propria and intestinal metaplasia (H\&E). 
Provenance and peer review Not commissioned; externally peer reviewed.

\section{REFERENCES}

1 Coyne JD, Azadeh B. Russell body gastritis: a case report. Int I Surg Pathol 2012;20:69-70.
2 Munday WR, Lucy Harn Kapur LH, Xu M, et al. Russell body duodenitis with immunoglobulin kappa light chain restriction. World J Gastrointest Endosc 2015;7:73-6.

3 Yoon JB, Lee TY, Lee JL, et al. Two cases of Russell body gastritis treated by Helicobacter pylori eradication. Clin Endosc 2012;45:412-16.

Copyright 2016 BMJ Publishing Group. All rights reserved. For permission to reuse any of this content visit

http://group.bmj.com/group/rights-licensing/permissions.

BMJ Case Report Fellows may re-use this article for personal use and teaching without any further permission.

Become a Fellow of BMJ Case Reports today and you can:

- Submit as many cases as you like

- Enjoy fast sympathetic peer review and rapid publication of accepted articles

- Access all the published articles

- Re-use any of the published material for personal use and teaching without further permission

For information on Institutional Fellowships contact consortiasales@bmjgroup.com

Visit casereports.bmj.com for more articles like this and to become a Fellow 